\title{
EKSPRESI METAFORIS DALAM PUISI-PUISI MARDI LUHUNG
}

\author{
Tsalits Abdul Aziz Al farisi
}

Ee-mail: drumbig_tsalis@yahoo.co.id

\begin{abstract}
This research aims to explore poem based on Michael Halley's space of metaphorical expression. It consistof nine metaphor category: human, animate, living, terrestrial, substance, energy, cosmic, being. Meanwhile, based on philosophic, there are etos, logos, and patos. The theory space of metaphorical expression Michael Halley is used on this. It says, hierarchy of human perception regarding space, start on his/her own perception. Because human and his/her action reflect the interaction with environment. That interaction is explained on metaphor. Meanwhile, the philosophic poin of the methaphor is about life. The message of life comes from the analysis of whole meaning, start on the explisit meaning or outside structure to the inplicit one. To find out the meaning, this research uses Friedrich Schleirmacher's hermeneutic and Pierce Semiotic approach. Those two theory support each other to analyze poem which consist of symbol and metaphor. This research uses analysis descriptive method. It describes the facts then analyzes those directly. On Mardi Luhung poems, researcher describes facts which form diction. After that, the diction which consist of metaphor is analyzed by observing the philosophic meaning. The result, the poet often to use methaphor which relate on space perception, in human category. This is the way to express his idea through poems. He uses nature symbols, animals, and myth, those have metaphoric and symbolic meaning as the way to express idea through poems.
\end{abstract}

Keywords: metaphorical expression, symbol, poem, human space perception, philosoph ic value.

Abstrak: Penelitian ini bertujuan untuk mengkaji puisi dari segi ruang ekspresi metafor Michael Halley yang terdiri dari sembilan konsep kategori metafor; yang meliputi human, animate, living, object, terrestrial, substance, energy, cosmic, being. Sementara pada ranah makna filosofis meliputi makna etos, logos dan patos. Teori yang digunakan pada penelitian ini menggunakan teori ruang ekspresi metafor Michael Halley yang menyatakan bahwa hierarki persepsi manusia terhadap ruang dimulai dari persepsi manusia itu sendiri, karena manusia dengan segala tingkah lakunya merupakan interaksi dengan lingkungannya. Interaksi dengan lingkungan tersebut diwujudkan berupa metafor. sedangkan pada nilai filosofis metafor berupa pesan-pesan kehidupan. Pesan-pesan kehidupan tersebut berangkat dari analisis terhadap keseluruhan makna, mulai dari makna eksplisit atau struktur luar hingga dengan makna implisit. Untuk menemukan makna tersebut menggunakan pendekatan hermeneutik Friedrich Schleirmacher dan Semiotika Peirce. Kedua teori tersebut saling mendukung dalam menganalisis puisi yang berupa paparan simbol dan metafor. Metode yang digunakan dalam penelitian ini adalah deskriptif analisis. Hal tersebut dilakukan dengan cara mendeskprisikan fakta-fakta yang kemudian disusul dengan analisis. Pada puisi Mardi Luhung, peneliti mendeskripsikan fakta-fakta berupa diksi yang mengandung metafor yang kemudian disusul denga analisis yang berupa makna filosofis puisi. Hasil penelitian yang ada dalam penelitian ini adalah banyaknya penggunaan metafor yang mengaitkan ruang persepsi pada kategori human sebagai ekspresi penyair dalam menuangkan gagasan pikirannya melalui puisi. Simbolsimbol alam, binatang dan mitos-mitos menjadi salah satu kreativitas pengolahan bahasa penyair yang diungkapkan secara metaforis dan simbolis.

Kata kunci: ekspresi metaforis, simbol, puisi, nilai filosofis, ruang persepsi manusia 


\section{PENDAHULUAN}

dalam menciptakan puisi $\begin{array}{r}\text { Pengalaman sangat } \\ \text { seorang }\end{array}$ ditentukan oleh situasi dan kondisi lingkungan alam, sosial dan kultural. Kondisi dan situasi tersebut dalam diri penyair bersifat abstrak, dalam arti kondisi yang bersinergi kedalam pikiran dan hati penyair diolah dengan pertimbanganpertimbangan internal penyair. Pertimbangan internal merujuk pada sikap dalam memandang fenomena-fenomena yang dilihatnya. Hal ini disebut sebagai pengalaman puitik. Pengalaman puitik dialami oleh setiap penyair, salah satunya Mardi Luhung merupakan salah satu penyair yang memiliki estetika pilihan kata yang khas, yaitu kepiawaiannya memadukan pilihan kata yang khas lokal pesisiran hingga yang binal. Penyair memiliki ketepatan dalam memakai diksi, kosa kata, maupun kalimat yang sesuai dengan fenomena yang ia lihat. Clifford Geertz (2003: 253) menyatakan bahwa semua aspek kehidupan seperti berlayar, berkebun, politik, puisi, hukum, etnografi pengetahuan dan ketrampilan-ketrampilan lain bekerja atas dasar pengetahuan lokal. Pengetahuan berasal dari pemahaman dan interpretasi hasil pengamatan, pengalaman, pendidikan formal dan informal. Penyair memiliki intensitas pengetahua lokal dan nilai-nilai spiritual dalam membuat karya sastra. Hal tersebut terbentuk melalui kode-kode yang dimanifestasikan dalam sebuah kalimat yang indah pada puisi sebagai hasil imajinasi penyair.

Melalui imajinasi, penyair mengawali tulisannya sebagai tulisan yang bersifat ekspresif. Luapan emosi penyair dituangkan melalui tulisan yang sudah dirancang secara simbolis maupun metaforis. Imajinasi penyair tidak berangkat dari kekosongan budaya. . Dalam diri penyair sudah banyak informasi dari berbagai segi yaitu agama, sosial, kemanusiaan, kebudayaan dan seterusnya. Dalam hal ini, penyair memiliki kredibilitas pilihan kata (diksi) dan estetika dalam mengungkapkan realitas yang kreatif. Hal tersebut senada dengan pernyataan Atmazaki bahwasanya Sastra merupakan ekspresi pikiran dan perasaan manusia maupun pengarang (penyair) dihasilkan dari realita yang diangkat dari imajinasi sehingga menghasilkan bentuk tulisan yang mengandung unsur realis dan imaji, diolah dengan bahasa yang estetis yang tidak mungkin dipisahkan dari proses kreatif. Pengalaman rohani maupun non-rohani, karena tidak mungkin karya sastra sepenuhnya menelaah kenyataan seperti sejarah, sehingga sastra merupakan perpaduan antara imajinasi dan kenyataan (Atmazaki, 1990:40) Puisi-puisi Mardi Luhung juga tidak sepenuhnya lepas dari sejarah dan pengalaman rohani penyair. Puisi-puisi Mardiluhung terdiri dari tiga kumpulan puisi yaitu Ciuman Bibirku yang Kelabu yang terdiri dari 68 puisi. Buwun terdiri dari 18 puisi serta Belajar Bersepeda terdiri dari 30 puisi. Ketiga kumpulan ini memiliki fase-fase proses pengalaman puitik yang berbeda-beda. Pada kumpulan puisi Ciuman Bibirku yang Kelabu, Mardi Luhung sering menggunakan idiom-idiom pesisiran yang dikaitkan dengan fenomena alam, misalnya desir sayap yang leleh, perut angin yang membentang, ombak yang kejam dan seterusnya.

Pada kumpulan puisi yang berjudul Buwun. Pada kumupulan puisi ini, Mardi Luhung mengolah ekosistem yang ada di pulau Bawean dengan mengamati setiap detil peristiwa alam dan budayanya, seperti tradisi keagamaan, selametan, dan ritual-ritual lokal lainnya. Dalam kumpulan puisi Buwun ini Mardi Luhung juga mengeksplor benda-benda mati yang diperlakukan seperti benda hidup. Seperti pulau dan batu yang digambarkan sebagai 
wanita cantik, yang siap dipersunting kapan pun.

Pada kumpulan puisi Belajar Bersepeda, Mardi Luhung menekankan pada mozaik-mozaik cerita berbingkai dalam satu judul puisi. Satu judul puisi, tidak mewakili keutuhan, hal ini sepertinya merupakan estetika metaforis tersendiri dalam persanjakkan Mardi Luhung terhadap puisi-puisi sebelumnya yang boleh dikatakan puisi naratif. Pada kumpulan puisi Belajar Bersepeda ini Mardi Luhung menggunakan potonganpotongan cerita yang dibingkai menjadi satu permasalahan seperti pada puisi yang berjudul Cacing Tanah yang secara umum puisi tersebut menceritakan tentang Syekh Siti Jenar dengan kulit cokelatnya, dan ada peristiwa Sunan Kalijaga yang setia menjaga tongkat Sunan Bonang. Peistiwaperistiwa ini saling berkaitan dan berbingkai satu sama lain. Hal tersebut terjadi karena pengalaman Mardi Luhung yang secara intens membaca sejarah yang ditekuni dan pengalaman puitiknya yang dibangun dari peristiwa menjadi simbolik yang diejawantahkan dalam bentuk bendabenda yang ada disekitarnya. Peristiwa simbolik ini tidak digunakan sembarangan, melainkan dengan pengetahuan bahasa yang intens.

Pengetahuan berasal dari pemahaman dan interpretasi hasil pengamatan, pengalaman, pendidikan formal dan informal. Penyair memiliki intensitas pengetahuan lokal dan nilai-nilai spiritual dalam membuat sastra. Hal ini terbentuk menjadi kode-kode yang dimanifestasikan dalam sebuah kalimat yang indah pada puisi sebagai hasil imajinasi sang penyair. Lewat imajinasi, penyair mengawali tulisannya, imajinasi penyair tidak mungkin berangkat dari kekosongan budaya. Dalam diri penyair sudah banyak informasi, berbagai segi yaitu agama, sosial, kemanusiaan, kebudayaan dan lainnya yang akan menentukan hasil karyanya. Dalam hal ini, penyair memiliki kredibilitas pilihan kata dan estetika dalam mengungkapkan realitas yang kreatif. Dengan demikian, realitas digambarkan penyair dengan perasaan subjektif pengalaman yang ia miliki. Pengalaman tersebut dituangkan dengan bahasa-bahasa tertentu sehingga menimbulkan nuansa puitis.

Sastra merupakan ekspresi pikiran dan perasaan manusia maupun pengarang (penyair) dihasilkan dari realita yang diangkat dari imajinasi sehingga menghasikan bentuk tulisan yang mengandung unsur realis dan imajiantif serta diolah dengan bahasa yang estetis yang tidak dapat dipisahkan dari proses kreatif (Atmazaki, 1990:40). Salah satu teori yang dapat digunakan dalam menganalsis puisi adalah metafora.

Metafora merupakan bahasa yang diungkapkan secara simbolis baik tertulis maupun terujar. Metafora memiliki kedudukan yang fundamental bagi karya sastra (terutama puisi) untuk menyampaikan pesan yang tidak instan. Pesan tersebut disampaikan dengan bahasa-bahasa yang indah dan padat. Penyampaian dengan bahasa yang padat memungkinkan puisi memiliki sistem kode tertentu untuk menembus makna yang disampaikan oleh penyair.

Puisi memiliki sistem kode yang plural, dan memunculkan multi interpretasi sistem kode tersebut memunculkan pola-pola persanjakkan yang melompat-lompat dari peristiwa satu ke peristiwa yang lain memiliki relevansi yang sama meskipun pada teks persanjakkanya berbeda. Puisi dapat menggunakan dimensi teks yang bervarian memunculkan beragam ekspresi, dan ide secara tidak langsung sama dengan gagasan dan pikiran. Hal tersebut tidak menjadikan puisi sulit ditemukan maknanya. Puisi, Selain bermain-main dengan simbol, juga bersentuhan dengan metafor metafor dalam puisi memainkan peristiwa imajiner yang berusaha mencari 
pola-pola ruang estetik terhadap karya sastra. Metafora merupakan bahasa kiasan yang membandingkan objek empiris dengan objek lain yang memiliki nilai sama. Metafora tidak hanya berperan sebagai konsep yang menawarkan definisi perbandingan teks, metafora lahir dari pola-pola pengalaman sekaligus pengamatan penyair terhadap lingkungan sekitar.

Sementara itu, untuk menganalisis puisi yang penuh dengan pola-pola pengucapan yang terkadang sulit dipahami, peneliti mengumpulkan beberapa simbol terlebih dahulu sebelum memasuki rangkaian peristiwa metafor. Simbol-simbol ini tidak terlepas dari strukutur puisi yang saling berkaitan membentuk keseluruhan makna. Sehingga untuk menemukan simbol, peneliti melacak keterkaitan struktur teks dengan teks yang lain. Hal ini merupakan gejala komunikasi yang berkaitan dengan pengarang dan pembaca yang mengatakan bahwa karya sastra sebagai sistem tanda dan pembaca. Selain itu, karya sastra merupakan salah satu bentuk penggunaan sistem lambang yang memiliki struktur. (Aminuddin, 1997: 33)

Namun, pada ranah metafora, peneliti mengidentifikasi simbol metaforis yang merupakan hasil penemuan secara struktur didalam puisi. Untuk mendeskripsikan makna metaforis, peneliti menggunakan dasar klasifikasi metaforis Halley yang mengatakan bahwa metafora merupakan ruang konsep persepsi manusia untuk menemukan medan semantik. Ruang persepsi ini terdiri dari Being, Cosmic, Energy, Substantial, Terresial, Object, Living, Animate, Human (Wahhab, 2008:72). Ruang persepsi ini bersifat predikatif yakni lambang yang perananya menjelaskan objek. Konsep model Halley ini diambil dari lingkungan manusia dalam sistem ekologi yang tersusun secara teratur dalam satu hierarki.
Interaksi antar manusia, hewan, tetumbuhan dan alam sekitar.

\section{METODE}

Penelitian ini menggunakan metode deskriptif analisis dan pendekatan objektif. Metode deskriptif analisis merupakan metode penguraian, hal ini dilakukan dengan cara mendeskripsikan fakta-fakta yang kemudian disusul dengan analisis (Ratna, 2007:53). Pada puisi Mardiluhung, peneliti mendeskripsikan fakta-fakta berupa diksi yang mengandung metafor yang kemudian disusul dengan analisis yang berupa makna dalam puisi.

Pendekatan sebagai suatu prinsip dasar atau landasan yang digunakan seseorang sewaktu mengapresiasikan karya sastra. Adapun pendekatan yang digunakan dalam penelitian ini adalah objektif. Pendekatan objektif, yakni memusatkan perhatian pada analisis terhadap unsur-unsur (puisi) dengan unsur-unsur yang lain seperti metafora dan aspek-aspek yang menimbulkan sifat estetis.

\section{HASIL DAN PEMBAHASAN}

Hasil uraian analisis penelitian didasarkan pada fokus penelitian yang telah ditentukan, diantaranya adalah 1) kategori ruang persepsi metafor Michael Halley yang meliputi being, cosmos, energy, substance, terrestrial, object, living, animate, human. 2) makna filosofis metafor dalam puisi-puisi Mardiluhung yang terdiri dari etos, logos, patos.

\section{A. Kategori Manusia (Human)}

Kategori Human memusatkan perhatian pada metafor yang mengarah ke sifat-sifat perilaku manusia. Hal tersebut seperti kemampuan berfikir, mengerjakan sesuatu yang dapat mengubah kehidupan. Sifat predikasinya yaitu berfikir (intelegensi). Berfikir hanya dapat dilakukan oleh manusia sebagai makhluk yang tinggi derajatnya. Berikut beberapa 
petikan analisis puisi yang berkaitan dengan kategori human.

Yang cuma matanya saja menyala. dan dengusnya pernah mengisi setiap relunglubang. saat kita

yang telanjang mengingati kelalaian yang sering merangsek. Sambil membidik bagian tepi pelipis. (BW/Pulau/17/Hmn/1)

Membidik merupakan aktivitas yang dilakukan manusia. Aktivitas tersebut dilakukan dengan cara mengincar sesuatu yang menjadi sasarannya yaitu anggota tubuh manusia. Tubuh diinterpretasikan sebagai cermin kesopanan yang harus di jaga kehormatannya. Membidik merupakan kegiatan koreksi terhadap perilaku manusia sekaligus aktivitas yang dapat dilakukan oleh manusia, namun tidak untuk aktivitas selain manusia, misalnya hewan. Pembanding dari kata membidik yaitu pelipis. Secara literal di maknai sebagai bagian anggota tubuh manusia yang terletak di alis.

Simbol selanjutnya ialah mengintip, merupakan aktivitas mengawasi sesuatu dengan cara sembunyi-sembunyi tanpa sepengetahuan orang lain.

Seperti matahari dan bulan yang kerap mengintip. Dan

kerap saling mengirim kabar dan muslihat. Sampai setiap ketakmungkinan yang benderang menetes...... (BW/Kastoba/18/Hmn/2)

Matahari dan Bulan adalah benda angkasa yang berada di langit berfungsi sebagai tanda waktu antara siang dan malam. Matahari dan bulan di ibaratkan sebagai orang yang mengintip sesuatu secara sembunyi-sembunyi. Padahal nyatanya matahari dan bulan tidak dapat mengintip atau menyinari bumi secara sembunyi-sembunyi. Matahari dan bulan menyinari sesuai dengan hukum dan sifatsifat alam yang sudah diciptakan oleh Tuhan. Matahari dan bulan dalam teks ini dikaitkan dengan aktivitas berkomunikasi (kabar) yang dapat diinterpretasikan sebagai pemberi petunjuk yang bersifat rahasia. Hal tersebut dapat diinterpetasikan sebagai inspirasi yang datang dalam pikiran manusia secara simbolik.

Simbol selanjutnya adalah menangis yang secara harfiah dapat diinterpretasikan sebagai perasaan sedih, kecewa yang biasanya dilakukan oleh manusia. Hal tersebut ditunjukkan pada uraian puisi berikut:

Sebab pagi itu: laut di belakang menggeram. Jukung ditiris. Seseorang memukul kentongan. Ikan-ikan pun menyembul: "hai, hai, boleh dilihat, tak boleh dipukat!" dan di punggung ikanikan itu ada garis. Putih menyala. Katanya: "dulu, si naga sipit telah menitipkan jalur kapalnya di situ. Tapi, sayang malah tersesat. Menabrak karang.

Menangis. Jadi pulau!" ya, ya, pulau menangis dengan mata semakin sipit (BW/Pacinan/21/Hmn/3)

Kata menangis disandingkan dengan kata karang yang menunjukkan adanya keterkaitan sebab akibat. Menangis disifatkan kepada Naga Sipit yang secara simbol mengacu pada binatang atau benda-benda yang mengarah ke hal-hal etnis Cina, yaitu kelenteng. Interpretasi yang muncul dari teks ini adalah menceritakan tentang asal usul suatu tempat (Legenda) yang terdapat di daerah Pulau Bawean. Dalam faktanya, Pacinan adalah suatu tempat yang mayoritas berpenduduk Cina. Bisa jadi, daerah tersebut terbentuk dari kesalahan manusia yang melanggar kode etik yaitu mengambil ekosistem alam sana secara sembarangan. Hal tersebut dibuktikan dengan perkataan ikan yang tidak boleh di ambil melainkan hanya boleh di lihat. Menabrak karang dapat pula diinterpretasikan sebagai perasaan yang sakit. Karang sendiri secara fisik bersifat keras dan tajam.

Konsep lain yang juga berkaitan dengan kategori human terdapat pada baris pertama yang ditunjukkan pada kalimat 
laut di belakang menggeram. Kalimat tersebut jika dimaknai secara literal menimbulkan suasana yang mencekam. Bisa kita maknai secara kognitif bagaimana jadinya apabila laut menggeram. Laut merupakan tempat yang luas. Salah satu bencana yang sering di alami oleh setiap negara adalah bencana alam yang berpusat pada laut. Nilai rasa dari simbol menggeram memiliki nuansa yang berlebih seiring sifat laut yang sudah buas. Hal tersebut merupakan simbol dari perlawanan laut terhadap manusia semenamena mencari ikan yang dapat merugikan ekologi kelautan.

Simbol selanjutnya adalah menjahit dan menggunting, merupakan aktivitas manusia yang berkaitan dengan menambal benda seperti baju untuk memperbaiki kerusakan pada baju. Hal tersebut dapat dilihat pada teks berikut:

Dan di antara kamar itu/bundamu sibuk menggunting dan menjahit balik perut bapakmu./Seperti perajin yang cakap/bundamu pun menaburkan benih matang. (BW/Ketam/22/Hmn/4)

Ada dua metafor yang dikaitkan dengan kata perut yang dapat diinterpretasikan secara harfiah sebagai anggota tubuh yang berfungsi sebagai kantung penyimpan makanan. Namun, mengapa perut dijahit, dan digunting? Mardiluhung tampaknya ingin menyampaikan hal baru yang bersifat konotatif. Perut disimbolkan sebagai kantung yang menampung segala bentuk macam makanan. Sementara makanan yang masuk ke dalam perut tentu berasal dari hasil yang positif maupun negatif, dalam arti halal dan haram.

Namun, di sisi lain ada kalimat yang menyatakan bundamu pun menaburkan benih matang. Hal tersebut dapat pula diinterpretasikan sebagai harapan untuk mendapatkan keturunan yang baik (benih matang), atau yang sempurna. Sementara itu, mengapa gunting dan menjahit di kaitkan dengan perut bapak? Bisa saja ada makna perselingkuhan dalam rumah tangga. Hal tersebut diperkuat dengan kata menggunting dan menjahit yang dapat digambarkan sebagai membongkar untuk melihat apa yang terjadi, dan menjahit untuk menutupi keburukan seseorang.

\section{B. kategori Makhluk Bernyawa (animate)}

Jika kategori Human memusatkan metafora pada sifat-sifat manusia, maka, kategori Animate memusatkan perhatiannya pada makhluk bernyawa (tanpa menyertakan manusia) yang bersifat fauna. Predikasi dari metafora ini adalah kemampuannya berjalan, berlari, dan terbang. Kategori ini merupakan kategori yang menempatkan posisi hewan agar dapat diasosiasikan sebagai identitas manusia, seperti kumbang yang di asosiasikan sebagai laki-laki. Namun, semua asosiasi ini bergantung dari situasi konvensi teks dan kode semantik. Kode semantik tampak lebih ketat ketimbang konvensi teks karena kode semantik mengenal aturan-aturan kebahasaan. Sementara konvensi bergantung dari teks, simbol-simbol yang bersifat arbitrer.

Beberapa simbol yang berkaitan dengan kategori animate adalah (1) sapi, (2) tikus, (3) kupu-kupu, (4) burung gagak. Secara denotatif, sapi merupakan hewan gemuk, bertanduk dan dimanfaatkan dagingnya untuk kurban. Sapi sekaligus simbol pengorbanan untuk manusia. Sapi di konsepkan dengan kata berbisik yang berarti berbicara secara perlahan-lahan. Hal tersebut dapat dilihat pada petikan puisi berikut:

..... "apa kau kelak akan merindukan aku?

" begitu bisik si jagal pada sapi yang akan dijagalnya.

Bisik sendirian. Bisik yang ditangkap oleh

tampar,

lampu dan keliningan yang mengkilat.

Keliningan yang tergeletak dengan bau liur sapi yang sengak dan menusuk. 
Keliningan dengan ukiran rumit...... (BW/durung/33/Anm/1)

Kata berbisik merupakan sifat yang terdapat pada unsur manusia yang disematkan kepada hewan. Makna konotasi yang muncul adalah ungkapan perasaan sapi kepada manusia. Ungkapan ini bentuk dari pengorbanan sapi kepada manusia yang tega untuk menjadikan dirinya untuk dikurbankan dagingnya kepada manusia.

Sisi animate ini terletak pada sifat benda yang ada pada sapi, seperti tampar, liur, dan keliningan. Dari simbol-simbol ini maka tidak ada keraguan jika makna animate pada puisi tersebut adalah hewan yang mengeluh atas perbuatan manusia yang tega membunuh binatang piaraannya.

Sedangkan pada kata lampu, tampar merupakan simbol yang berkaitan dengan atribut yang dikenakkan pada kata sapi sebagai ranah sasaran (target domain), sehingga kedekatan interpretasi dari teks tersebut adalah nasib ditentukan oleh tampar dan lampu. Situasi teks tersebut merupakan metafora konseptual. Metafora konseptual menekankan pada ranah kognitif penafsir yang melibatkan sistem berfikir manusia dalam kehidupan sehari-hari.

Simbol selanjutnya adalah tikus yang di konsepkan dengan kata takjub yang dapat diinterpertasikan sebagai kekaguman atas apa yang dilihat. Tikus memiliki simbol yang beragam. Jika dikaitkan dengan teks puisi berikut maka akan memiliki interpretasi negatif. berikut petikan teks puisi yang dimaksud :

Gelembung yang setiap bergerak, selalu menyerakkan irama salung. Irama yang membuat ribuan tikus takjub.

Dan bersedekuh di seputar aku yang tertidur. (BW/pendalungan/41/Anm/2)

Makna negatif yang dikenakkan pada simbol tikus dalam puisi ini adalah irama salung yang membuat hewan pengerat ini menjadi takjub. Irama salung inilah yang menjadikan status metafor tikus menjadi bermakna negatif. irama salung ini disimbolkan sebagai pemberi pesan.

Ketakjuban tikus tersebut bukan berarti tikus memiliki status sosial yang rendah, melainkan koreksi pribadi agar apa yang diperoleh tetap bermanfaat. Ketakjuban ini bersifat paradoks dari kenyataannya.

Simbol cacing tanah secara harfiah dapat dimaknai sebagai ketidak berdayaan manusia. Karena dari segi fisiknya, cacing tanah merupakan hewan yang tidak berkaki, biasanya hidup di dalam tubuh manusia dan tanah. Dalam petikan puisi berikut, cacing di konsepkan dengan manusia.

....."demi hari yang kesepuluh. Dan demi hari yang ganjil yang berikutnya.Tak ada yang sampai kecuali yang dipinta! " lalu si cacing tanah yang lain, yang telah dimanusiakan lewat gelap malam itu pun segera membuka rahasia kulit coklatnya.....

(BB/cacing tanah/11Anm/4)

Cacing tanah sebelumnya sudah dijelaskan identik sebagai hal yang bersifat fisik rendah. Namun, dalam puisi berjudul Cacing Tanah, derajat cacing meningkat disetarakan sebagai manusia. Pada bait ke lima, ada pernyataan simbolik bahwa cacing telah dimanusiakan lewat gelap malam. Namun, pernyataan ini juga sekaligus bertentangan ada teks lain yang menyatakan bahwasanya cacing membuka rahasia kulit coklatnya. Rahasia ini merupakan simbol yang dapat dipetik dari simbol warna kulit coklat, yang dapat diinterpretasikan sebagai sifat yang buruk.

Kupu-kupu merupakan hewan cantik dengan sayap menawan yang biasanya terbang hinggap ke bunga untuk menghisap madu. Secara harfiah, citra кири-кири digambarkan dengan hal-hal yang menarik, dikaitkan dengan kecantikan, identik dengan perempuan yang menawan, dan lain sebagainya. Hal tersebut tampak berbeda jika kupu-kupu berada pada situasi teks karya sastra puisi. 
Seperti yang terlihat pada petikan puisi berikut:

Aku belajar bersepeda. Belajar di lembah. Dekat rumput, bunga dan kupu-kupu. Kupu-kupu yang jika malam tiba, selalu melepaskan rama-ramanya. Dan pulang telanjang ke dalam kerimbunan yang jauh ada di kenangan. Kenangan tentang sepasang kekasih yang selalu berjanji di pintu belakang

(BB/belajar bersepeda/21/Anm/5)

Ada beberapa simbol yang menentukan identitas kupu-kupu, yaitu telanjang, malam, dan kalimat pada bait terakhir yang menyatakan kenangan tentang sepasang kekasih yang selalu berjanji di pintu belakang. Metafor kupu-kupu di konsepkan dengan waktu malam yang dikonotasikan sebagai pelacur. Konotasi ini sudah menjadi konvensi umum karena kири-kири malam merupakan metafor dari perempuan yang menghibur di malam hari. Maka interpretasi yang muncul adalah pelacur.

Sedangkan telanjang merupakan simbol dari kehormatan yang telah hilang. Perempuan yang melepaskan keperawanannya demi kepentingan tertentu. Kepentingan ini dapat terungkap pada bait terakhir yang menyatakan kekasih yang selalu berjanji di pintu belakang yang dapat diinterpretasikan sebagai kekasih simpanan (kekasih gelap). Kalimat berjanji di pintu belakang merupakan simbol dari sesuatu yang disembunyikan, dirahasiakan. Pada metafor belajar di lembah lebih dekat maknanya dengan kebebasan. Karena belajar dikonsepkan dengan lembah yang berkonotasi luas. Interpretasi metafora konseptualnya adalah kebebasan dalam mempelajari segala hal yang ada di dunia.

Burung gagak identik dengan simbol kematian. Burung yang berbulu hitam dan pemakan bangkai. Simbol yang disematkan pada hewan ini merupakan konvensi sekaligus kode dari serangkaian cerita yang umum kita jumpai. Dalam arti konvensi karena hewan ini sudah menjadi bagian dari tradisi masyarakat yang menyatakan kehadirannya adalah pertanda kematian. Sedangkan dalam arti kode, hewan ini selalu dikaitkan dengan kematian, bukan untuk yang lain. Pemaknaan kode ini sungguh ketat dan jelas. Hal tersebut dapat dilihat pada petikan puisi berikut:

Ketika kau mati, aku tak mati. Dan karena tak mati, aku jadi sendirian, sepi. Cuma bisa melihat kuburanmu. Kuburan dengan warna kelabu, kotor, dan sesekali dikitari gagak galak yang nyalang. Gagak galak yang keluar dari balik halimun. Gagak galak yang selalu mengelak,ketika ada yang melemparinya dengan batu..... $(\mathrm{BB} /$ ketika matinya musuh utama/32/Anm/6)

\section{Kategori Living}

Kategori Living memusatkan perhatiannya pada semua makhluk hidup tumbuh dan berkembang biak selaras dengan kehidupan ini. Tidak semua makhluk hidup termasuk dalam kategori ini karena hanya terbatas pada segala macam flora dengan predikasi tumbuh.

Beberapa simbol living dalam puisi-puisi Mardi Luhung antara lain meliputi (1) tiup, (2) mekar, (3) benih. Kategori-kategori ini berangkat dari situasi teks secara keseluruhan yang mengidentifikasi kategori tersebut. Dalam kategori ini, ada beberapa metafor yang tidak selalu berupa kata atau kalimat yang menggunakan diksi tumbuh yang dikaitkan dengan flora. Tetapi ada simbol yang secara tekstual mengarah ke predikasi tumbuh.

Simbol tiup di konsepkan dengan bidadari yang memunculkan interpretasi kelahiran seorang perempuan dari hasil hubungan tertentu. Metafor tiup ini dikonotasikan sebagai pembuahan, hubungan lawan jenis (laki dan perempuan). Hal tersebut dapat dilihat pada petikan puisi berikut: 
Kau adalah bidadari yang ditiup dari bahan tersisa. Karenanya tak begitu istimewa. (BB/Habsiyah/14/lvg/1)

Sekilas, makna pelacur tidak diragukan lagi karena ada beberapa simbol yang menyatakan tentang pelacur yaitu pada frasa bahan tersisa yang diinterpretasikan sebagai barang yang sudah pernah digunakan. Bahan tersisa ini dapat dikonotasikan sebagai perempuan yang sudah tidak perawan. Maka, muncullah kalimat pada bait terakhir yang menyatakan ketidak istimewaan terhadap kelahiran manusia yang dianggap sia-sia. Wujud kelahiran ini disimbolkan sebagai di tiup.

Simbol berikut yaitu bermekaran yang diasosiasikan sebagai tumbuhtumbuhan yang mulai berkembang. Metafor ini di konsepkan dengan bulu roma yaitu bulu yang tumbuh di kulit manusia yang dapat diartikan sebagai perasaan merinding (ketakutan). Hal tersebut dapat dilihat pada petikan puisi berikut:

..... "kami tak mengintip kalian. Kami cuma merasa ada jalan lain mencapai sana. Seperti tangga yang terus terulur. Yang bahannya dari apa yang tak mempan kami beli. Dan bermekaran di bulu roma" (BB/Bulu roma/35/Lvg/2)

Bulu roma bermekaran identik dengan perasaan yang merinding. Perasaan ini disimbolkan dengan mekarnya bulu manusia yang tumbuh. Perasaan takut ini bukan tanpa sebab. Ada frase yang menyatakan jalan untuk melangkah ke suatu tempat tidak hanya tunggal melainkan banyak jalan. Interpretasi yang muncul dalam frase ini adalah jalan rezeki seseorang yang tidak searah, namun banyak cara yang perlu dilalui.

Apabila akan menanam pohon, pastilah dimulai dari bibit dahulu (dikatakan benih) dan setelah ditanam maka seiring dengan berjalannya waktu benih pohon itu akan tumbuh besar, manusia juga memiliki bibit atau benih rasa yang ada dikandungan hatinya. Hal tersebut dapat dilihat pada petikan puisi berikut:

... "jika semuanya memang hanya berputar,berputar dan berputar." Meski sesekali rehat. Dan sesekali menukar apa yang disebut benih di dalam dada sebagai tanda mata. Tanda mata yang akan bertumbuhan di mana saja...

Pada petikan puisi di atas, benih diinterpretasikan sebagai tanda kehidupan yang lahir dalam diri, dalam arti semangat yang lahir dari berbagai tekad untuk tujuan tertentu. Ada simbol yang mengarah pada nilai-nilai kepercayaan, yaitu dada yang diasosiasikan dengan kata benih. Asosiasi secara kognitif yang sudah umum terjadi pada simbol dada yang berkaitan dengan sifat-sifat keberanian manusia. Sedangkan tanda mata dalam puisi ini dapat disimbolkan sebagai pengawas. Dalam konteks ini evaluasi diri untuk tetap semangat menatap masa depan.

Tumbuh merupakan bagian dari tanaman yang semakin membesar kemudian matang. Tumbuh juga dapat diasosiasikan dengan bagian tubuh manusia, seperti rambut, kuku, gigi, tulang dan lain sebagainya. Namun, dalam puisi berikut ini, tumbuh di konsepkan dengan gigi.

....Aku tahu, kau kini terambing di antara dua sisi. Dan diantara dua sisi itu, diamdiam sepasang taringku pun menumbuh. Taring yang langsing dan berkilau. Dan taring yang berdebar setiap melihat jenjang lehermu..... (BB/Salak/57/Lvg/4) Taring yang tumbuh dapat dimaknai sebagai ancaman. Taring identik dengan gigi binatang buas, bukan diasosiasikan dengan manusia. taring identik dengan binatang seperti serigala, singa, harimau, dan binatang pemakan daging lainnya.

Sedangkan pada bait terakhir kalimat yang menyatakan "taring yang berdebar setiap melihat jenjang lehermu" merupakan metafora konseptual dari 
perasaan yang mengancam. Ancaman ini disimbolkan pada kata leher yang secara empiris lebih dekat dengan urat nadi manusia. Urat nadi sangat dekat dengan kelangsungan hidup manusia.

\section{D. kategori Object}

Kategori ini memusatkan perhatiannya pada benda-benda yang terdiri dari semua jenis mineral dan benda bernyawa lainnya. Predikasi benda ini adalah benda yang dapat pecah semisal piring, cermin, guci, genting dan lain sebagainya.

Salah satu simbol object dalam puisi-puisi Mardi Luhung antara lain; (1) Genting, (2) Tali. Genting adalah benda yang digunakan sebagai penutup atap rumah, berfungsi sebagai pelindung agar tidak terkena hujan dan panas. Dalam puisi Pendalungan, genting berfungsi sebagai tempat untuk istirahat. Hal tersebut dapat dilihat pada petikan puisi berikut:

\section{Di genting aku tertidur dan bersiap menantimu}

Tertidur seperti mayat yang matanya terbuka

Terpulas warna samar sampai gelap pekat. (Bwn/Pendalungan/41/Obj/1)

Genting dikonsepkan dengan tempat tidur, yang disimbolkan dengan kalimat bait pertama: tertidur dan bersiap menantimu yang berarti menunggu seseorang hingga tertidur pulas. Pada bait kedua, ada perbandingan secara eksplisit yang menyatakan tertidur seperti mayat yang matanya terbuka. Mata terbuka dapat dikonotasikan sebagai mengawasi. Mata yang terbuka pertanda seseorang dalam kondisi terjaga (waspada). Waspada dalam hal menanti seseorang yang akan datang. Sedangkan pada bait terakhir menyatakan tentang waktu sore hari. Hal tersebut dapat dilihat pada kalimat warna samar sampai gelap pekat yang disimbolkan sebagai sore hari hingga malam hari.

Simbol selanjutnya yaitu tali yang berarti benda yang digunakan untuk mengikat sesuatu agar tidak lepas. Metafor tali di konsepkan dengan rambut manusia. Hal tersebut dapat dilihat pada petikan puisi berikut:

Oh, punggungmu memenuhi perahumu. Sedang rambutmu berjuntai seperti tali yang ruwet. Yang barangkali jika dicabut satu akan jadi titian. Seperti titian yang pernah aku pasang... (BB/Kau tiba dengan perahumu/4/Obj/2)

Rambut dalam kehidupan seharihari merupakan identitas seseorang untuk melihat usia seseorang. Jika rambut beruban (putih) maka interpetasi dalam benak seseorang akan mengatakan bahwa orang tersebut sudah tua. Begitu juga ketika melihat rambut yang sudah jarang tumbuh di kepala (botak) bisa memunculkan makna beberapa makna, yaitu usia lanjut dan seorang pemikir.

\section{E. Kategori Terrestrial}

Kategori Terrestrial ini merupakan terusan dari kategori sebelumnya, yaitu Object. Namun, kategori Terrestrial memusatkan perhatiannya pada objekobjek yang bersifat alam bebas. Alam ini terikat oleh bumi. Seperti sungai, gunung, samudra, padang pasir, dan lain-lain. Predikasi kategori ini adalah terhampar. Metafor yang terdapat dalam kategori ini meliputi: (1) Pantai, (2) Laut, (3) Waduk.

Pantai merupakan tempat yang indah yang berada diperbatasan antara laut dan daratan. Terkadang pantai menjadi tempat yang inspiratif untuk menuangkan segala macam perasaan, masalah, bahkan kreativitas. Metafor pantai dalam puisi ini dikonsepkan dengan Tinta yang merupakan unsur dari alat untuk menulis. Hal tersebut dapat dilihat pada petikan puisi berikut:

Sayangnya, Nabi tak pernah diturunkan di sini. Dan dia pun cuma bisa menghela nafas. Barangkali memang buku itu tak bisa diselesaikan. Barangkali juga kisah kampung akan mengabur. Tintanya 
merembes ke pantai. Terserap di pasir. (Bwn/Kampung kuning/29/Terre/1)

Tinta dapat disimbokan sebagai kisah. Setiap tulisan memiliki kisah dan sejarahnya masing-masing. Sebuah tulisan, ditulis dengan alat yang bernama tinta. Tanpa tinta sejarah tidak akan ditulis dan dimanfaatkan untuk generasi masa depan. Dalam puisi ini, tinta beratribut dengan pantai yang sekaligus frasa dari kalimat merembes ke pantai yang memiliki simbol sejarah yang telah hilang diterpa oleh pantai. Sementara sifat pantai yang terhampar luas hingga tinta tersebut sudah menjadi bagian dari pantai (hilang).

Makna yang muncul dari keseluruhan teks ini adalah kisah asal usul suatu daerah (kampung) yang memiliki unsur-unsur religi. Hal tersebut dapat ditangkap pada bait pertama yang menggunakan subjek Nabi yang dapat diinterpretasikan sebagai orang yang suci. Simbol selanjutnya adalah Laut. Laut ini tampak bersinonim dengan pantai. Perbedaannya terletak pada tempatnya saja. Jika laut lebih berada pada hamparan yang luas, maka pantai berada pada tepi laut yang menjadi perbatasan antar pulau dengan pulau lain. Laut bersifat terhampar yang di konsepkan dengan kata terbuang yang merupakan kalimat keterangan dari metafor laut. Hal tersebut dapat dilihat pada petikan puisi berikut:

....hutan yang kangen pada sumur-sumur yang ada di bulan. Yang diharap segera terguling. Dan menumpahkan airnya jadi hujan di bumi. Hujan yang akan membuat banjir. Dan menyeret setiap yang jahat agar terbuang ke laut.... (BB/Kunjungan Hiu/7/Terre/2)

Laut dalam puisi ini adalah tempat untuk membuang sial. Hal tersebut dapat dilihat pada kata sifat jahat yang terdapat pada bait ke lima. Jahat dapat dikonotasikan sesuatu yang tidak dikehendaki untuk segera di musnahkan.
Yang dimaksud dalam konteks ini adalah banjir yang selalu membawa bencana.

Ada beragam simbol yang memiliki keterkaitan dengan datangnya banjir. Hal tersebut dapat dilihat pada bait pertama yang merupakan kalimat metafor hutan yang kangen pada sumur yang ada di bulan yang diinterpretasikan sebagai keinginan untuk datangnya hujan. Bulan disimbolkan sebagai malaikat. Bulan menyinari segenap yang ada di hutan. Ada semacam bentuk permohonan mengharap datangnya hujan.

Waduk merupakan kolam besar penyimpanan air untuk berbagai keperluan jika musim kemarau tiba. Dalam puisi ini, waduk digunakan sebagai tempat untuk menampung kesedihan.

...dan perut yang jika gerhana tiba akan menjelma sebentuk waduk yang lebar dan dalamyang ketika aku goyang pun memantulkan sebentang cermin... (BB/Menor/52/Terre/3)

Waduk dalam puisi ini dikonsepkan dengan cermin yang sebelumnya sudah pernah dibahas pada kategori Object. waduk jika airnya tenang akan memantulkan segala kehidupan yang ada di atasnya, dalam hal ini segala bentuk kesedihan. Kesedihan ini dikonsepkan pada gerhana yang secara konotatif memiliki sifat-sifat yang menutup pintu jalan keluar untuk memecahkan permasalahan hidup. Menurut konvensi umum, gerhana bermakna kesulitan. Gerhana menyulitkan Bulan dan Matahari yang disimbolkan sebagai penerang dunia.

\section{F. Kategori Substance}

Kategori Substance memusatkan perhatiannya pada predikasi yang bersifat ada, menempati ruang, dan bergerak. Kategori ini juga mempunyai sifat lembam, misalnya air, es udara, hidrogen, oksigen, karbondioksida, dan seterusnya.

Simbol yang ada pada kategori substance antara lain meliputi: (1) Lenyap, (2) Tabung gas, (3) menguap. Lenyap 
dikonotasikan sebagai suatu benda yang hilang akibat terjadinya pergesekan di udara. Simbol lenyap di konsepkan dengan benang yang dapat diinterpretasikan sebagai hubungan yang telah lenyap di udara. Hubungan ini lenyap akibat ketinggian. Hal tersebut dapat dilihat pada petikan puisi berikut:

Di udara yang tipis, benang itu terentang Lurus dan lenyap di ketinggian Lewat benang itulah kau akan tiba padaku. Mungkin memelukku.

(Bwn/Pendalungan/41/Subs/1)

Simbol benang di metaforkan dengan lenyap memunculkan interpretasi yang bermacam-macam. Jika dimaknai secara denotatif, maka benang hilang akibat putus di udara. Sementara secara konotatif, interpretasi yang muncul adalah benang lenyap akibat terlalu tinggi di udara, sehingga seolah-olah tidak tampak. Konotasi ini melihat sesuai dengan suasana teks, namun, heremeneutik memandang teks yang saling berkaitan. Benang merupakan tangga untuk mempertemukan seseorang yang ada di udara. Hal tersebut bisa disimbolkan sebagai surga.

Simbol surga erat kaitannya dengan ketuhanan yang ditunjukkan pada baris terakhir yang menyatakan kerinduan kepada Tuhan. benang sebagai simbol alat untuk dapat berkomunikasi dengan Tuhan. jika dilihat dari sudut pandang metafora linguistik, maka kata benang merupakan alat perantara komunikasi kepada Tuhan. ranah sumber dalam petikan baris terakhir adalah subjek "aku", sedangkan ranah sasaran terletak pada kata "memelukku". Objek yang akan memeluk bersifat abstrak. Secara konotatif bisa ditafsirkan sebagai Tuhan karena ranah sasaran jika dilihat secara konseptual mengarah kepada Tuhan.

Tabung gas adalah benda yang berisi udara yang mudah terbakar yang biasanya dimanfaatkan untuk keperluan memasak. Tabung gas merupakan simbol kehidupan masyarakat umum. Simbol ini menjadi kode bahasa dimana Tabung indentik dengan Gas, elpiji, oksigen dan lain sebagainya. Tabung gas di konsepkan dengan kata kerja menggendong. Hal tersebut dapat dilihat pada petikan berikut: Aku hadir ketika minyak tanah digelapkan dari neraca warung Orang-orang dipaksa menggendong tabung gas Dan si tuan mengawini perempuan dari gurun.(BB/Lorong/17/Subs/2)

Ada dua simbol menarik yang menuntut untuk menemukan makna dari petikan puisi Lorong tersebut, yaitu simbol neraca warung, dan perempuan dari gurun. Pada simbol pertama yaitu berupa metafor neraca warung yang diinterpretasikan sebagai barang dagangan. Kata neraca bermakna alat untuk mengukur. Sementara warung identik dengan barang dagangan, seperti toko. Namun, warung berkonotasi rendah yang biasa berada di kampung dan pinggir jalan. Sementara perempuan dari gurun merupakan simbol dari rakyat Timur Tengah. Gurun identik dengan hamparan pasir yang luas.

Menguap adalah gejala kimia dari benda cair yang dipanaskan menjadi gas. Menguap bersinonim dengan lenyap, hilang, musnah dan seterusnya. Simbol ini di konsepkan dengan darah yang berarti sesuatu yang berkaitan dengan makhluk hidup yaitu manusia. Hal tersebut dapat dilihat pada petikan puisi berikut:

...Dan saat ini, konon kabarnya: dia adalah pemuja bulan, sekaligus pembenci matahari. Dan konon kabarnya juga: dia kini tak lagi punya darah warna merah seperti darahmu. Tapi darah ungu. Darah yang selalu akan menguap setiap terkena sinar matahari...(BB/Penulis puisi yang gaib/31/Subs/3)

Simbol-simbol pemuja bulan dan pembenci matahari tampak sekali berkaitan dengan sejarah pra islam yang ada di negara Arab. Pemujaan ini berupa upacara keagamaan astral (berhubungan 
dengan benda-benda langit) dalam arti mereka melibatkan bulan sebagai sesembahan mereka. Sedangkan matahari menurut pandangan kaum Komaruddin (kaum pemuja bulan zaman pra islam) disebut sebagai dewa pembawa bencana.

Sedangkan simbol darah ungu yang dikonsepkan dengan menguap kemungkinan besar ada kaitannya dengan keturunan bangsa yang unggul (darah biru). Namun, pada puisi ini tidak menggunakan biru namun ungu. Besar kemungkinan sang penyair ingin menciptakan simbol baru yang berkaitan dengan efek darah yang terkena sinar matahari.

\section{G. Kategori Energy}

Kategori ini memusatkan pada sesuatu yang dapat bergerak dan menempati ruang. Manusia membutuhkan Energy untuk melakukan aktivitas. Energy mendorong manusia bersemangat dalam melakukan segala aktivitas dan menggerakkan sesuatu. Contoh nomina pada kategori ini adalah cahaya, api, angin. Sedangkan predikasinya adalah bergerak.

Simbol-simbol dalam kategori energy antara lain meliputi kalimat Api yang melayang dan matahari. Pada dasarnya api tidak dapat melayang kecuali ada dorongan energy tertentu yang membuatnya bergerak melayang. Dalam puisi yang berjudul Sinai, api diperintahkan untuk terbang. Ada unsur perintah yang menyebabkan api menjadi bergerak. Hal tersebut dapat dilihat pada petikan puisi berikut:

Kau berkata api, dan perkataanmu itu jadi api Api yang melayang. Menukik tegak lurus ke bawah Menuliskan kitab-kitab api...(BB/Sinai/16/Ene/1)

Api yang melayang disimbolkan sebagai api yang memiliki semangat yang tinggi. Semangat ini diwujudkan dengan menulis kitab-kitab hasil dari semangat menyalurkan ilmu. Simbol kitab-kitab api memiliki makna yang luas. Kitab-kitab api dapat ditemui pada novel John Stephens berjudul The Fire Chronicle yang menceritakan seorang anak yang mencari kedua orang tuanya melalui seorang penyihir. Penyihir ini memberi anak tersebut kitab api yang menjadi petunjuk untuk menemukan orang tuannya. Apakah kitab api pada puisi Mardiluhung ini berkaitan dengan novel John Stephens? Hal tersebut kemungkinan besar terjadi. Karena ada unsur perintah dalam novel tersebut. Hal ini sesuai dengan intonasi puisi yang menginterpretasikan perintah kepada api.

Simbol matahari sebelumnya sudah sering diperbincangkan yang diinterpretasikan sebagai pengayom masyarakat, cahaya kebenaran dan seterusnya. Dalam puisi yang berjudul Memasuki Kampung. Matahari menjadi simbol petunjuk waktu pagi. Hal tersebut tercermin pada petikan puisi berikut:

...ada tahlil yang cukup panjang. Tahlil yang penuh tanya: "kemana akan dikubur si mati. Jika kencing-Mu tak pernah surut-surut? Apa perlu dibiarkan. Untuk disimpan di selipan atap? Akh" matahari pun meninggi. Dan kampung pun berkilauan seperti lepek yang memantul.... (BB/Memasuki kampung/23/Ene/2)

Simbol Matahari dikonsepkan dengan meninggi yang diinterpretasikan sebagai matahari terbit yang menandakan waktu pagi. Sedangkan kalimat pad baris terakhir yang menyatakan kampung pun berkilauan merupakan metafor yang diinterpretasikan sebagai kampung yang mendapat anugerah Tuhan. Anugerah ini dapat dilihat pada simbol tahlil dan kencing. Kencing lebih bersifat paradoksal. Artinya kencing merupakan anugerah yang datang dari Tuhan. Walaupun simbol yang digunakan mencitrakan hal yang negatif.

\section{H. Kategori Cosmic}

Kategori ini memusatkan perhatiannya pada benda-benda angkasa. 
Namun, berbeda dengan kategori Energy yang menggunakan benda-benda angkasa yang bersifat bergerak, kategori Cosmic menggunakan benda-benda angkasa seperti Bulan, Bumi, Matahari, bintang, sebagai ruang untuk mengekspresikan diri, untuk menyatakan pandanganpandangannya terhadap dunia. Simbolsimbol yang menggunakan kategori ini meliputi: bulan dan pemuja bulan, pembenci matahari.

Simbol Bulan pada kategori cosmic ini ada empat. Namun memiliki makna dan fungsi yang berbeda-beda. Simbol bulan pada puisi yang berjudul Bagaimana aku bisa tak percaya memiliki interpretasi bentuk fisik bulan yang dijadikan objek perasaan manusia. Perhatikan petikan puisi berikut:

Apa mereka bedua sedang bercinta? Dan apa benar sepedaku bisa bercinta? Sedang, jauh di langit sana, bulan pun sudah tak lagi bundar. Tapi, sedikit berubah. Seperti sekepal jantung yang segar. Jantung yang menggemaskan.

(BB/Bagaimana aku bisa tak percaya/25/Cos/1)

Simbol bulan dikonsepkan dengan kalimat sudah tak lagi bundar yang berposisi sebagai tenor memiliki interpretasi bulan yang tidak sanggup lagi menerangkan cahayanya yang indah. Bulan juga di citrakan dengan jantung yang dikonotasikan sebagai nyawa. Bulan seperti nyawa yang gelisah, nyawa yang siap untuk melayang. Nyawa yang gelisah ini berkaitan dengan baris terakhir yaitu jantung yang menggemaskan. Jantung dalam petikan puisi tersebut mengarah pada perasaan yang gelisah. Konteks tersebut dapat disebut sebagai metafora konseptual yang menekankan aspek kognitif pembaca. Aspek tersebut berasal dari peristiwa abstrak yang dikaitkan dengan hubungan atribut, pola-pola kalimat yang dipetakan berdasarkan pada ranah sumber. Kata-kata atau ungkapan inilah yang disebut dengan metafora linguistik. Metafora linguistik adalah ungkapan linguistik yang dihasilkan dari sebuah metafora konseptual.

Puisi yang berjudul Penulis yang gaib ini sudah pernah disinggung pada kategori Substantial. Namun jika dikaitkan dengan makna, tentu berbeda. Jika pada kategori substansia berfokus pada masalah ruang yang lembab. Semisal uap.

Sedangkan dalam kategori Cosmic pada puisi yang berjudul penulis yang gaib metafor lebih bersifat ekspresif kepada topik vehicle. Hal tersebut dapat dilihat pada petikan berikut:

...dan saat ini, konon kabarnya: dia adalah pemuja bulan sekaligus pembenci matahari. (BB/Penulis puisi yang gaib/31/Cos/2)

Bulan dan matahari sebagai ruang ekspresi untuk melampiaskan amarah manusia yang memiliki tujuan tertentu. Makna yang muncul pada metafor ini adalah penyuka perempuan, sedangkan pembenci matahari diinterpertasikan sebagai orang yang membenci semangat hidup. Metafor ini juga bisa dikaitkan dengan perisitiwa zaman pra islam yang masyarkatnya lebih mengagungkan bulan ketimbang matahari. Konsep ini sudah pernah dibahas sebelumnya pada kategori Substantial.

\section{Kategori Being}

Kategori ini memusatkan perhatiannya pada sesuatu yang abstrak. Sesuatu yang tidak dapat langsung dihayati oleh indera manusia tetapi sangat dibutuhkan. Seperti: kasih sayang, kebenaran, cinta, perasaan senang yang semuanya mengandung sifat keadaan (kondisi) yang abstrak. Kategori ini merupakan kategori yang paling abstrak. Kategori inilah yang urutannya paling atas dalam metafora Mihael Halley.

Dalam puisi-puisi Mardiluhung, Kategori ini paling sedikit keberadaannya. Yaitu ada empat macam yang kesemuannya berupa kalimat. Alasan mengambil simbol berupa kalimat karena 
kategori ini tidak dapat dilacak simbol yang bersifat klausa maupun frasa. Peneliti mengambil kalimat yang sifatnya filosofis, walaupun ada beberapa diksi yang sekiranya bernuansa metafor. Berikut kalimat-kalimat yang terdapat pada kategori Being : (1) terlalu banyak ular merah yang merayap di batu merah pada maghrib yang merah! (2) Sebelum senja terbit

Satu kalimat pada puisi berikut ini mengandung beragam metafor. Untuk melacak makna dari teks tersebut, peneliti mencoba mencari satu frasa yang sekaligus berupa metafor yaitu ular merah. Konotasi yang muncul dari frasa ini adalah ular yang baru lahir. Sehingga warna merah berkonotasi sesuatu yang baru lahir, tidak terikat oleh binatang saja, melainkan manusia juga menggunakan konvensi merah sebagai simbol kelahiran. Untuk lebih jelasnya, mari kita lihat petikan puisi berikut:

..."mengapa di kota yang hujannya telah dibungkus, kita begitu tak leluasa menyebut si yang liyan dengan satu tarikan napas?" ternyata, adik menjawab Cuma satu:

\section{"terlalu banyak ular merah yang merayap di batu merah pada maghrib yang merah!" (BB/Pesan/42/Bei/1)}

Warna merah juga dikonsepkan pada batu dan menandakan waktu magrib. Semua itu berupa metafor. Pada metafor batu merah bisa diinterpretasikan sebagai bentuk kelahiran. Hal ini mempunyai alasan subjektif, karena peneliti memandang dari sudut sifat-sifat batu yang berasal dari tanah. Sedangkan pada metafor magrib yang merah diinterpretasikan sebagai senja telah tiba, makna ini muncul karena berkaitan dengan fakta-fakta empiris dimaan waktu magrib, langit menjadi merah pertanda senja tiba.

Kaitannya dengan ular disini adalah ular bersifat memata-matai. Sifat ini berangkat dari sikap rasa ingin tahu sekaligus ketidak percayaan seseorang kepada lawannya. Sehingga ia mengintai lawannya yang bertujuan untuk mengetahui apa yang akan direncanakan sekaligus dibuat.

Kalimat selanjutnya adalah sebelu senja terbit yang sekaligus berupa metafor dari kata senja dan terbit. Interpretasi yang muncul ialah awal dari kehidupan, awal manusia untuk menjalankan aktivitas sehari-hari.

..."bepergianlah sejauh mungkin Tapi kembalilah sebelum tersesat." Sebelum senja terbit. (BB/Tali kekang/55/Bei/2)

Ketika seseorang melakukan aktivitas sehari-hari, ia meninggalkan istri dan anak-anaknya. Makna ini cukup beralasan karena ada situasi teks yang menyatakan bepergianlah sejauh mungkin, tapi kembalilah sebelum tersesat. Teks ini sekaligus menjadi pesan bagi seseorang yang ingin merantau. Ada unsur paradoks dalam teks ini yang ditunjukkan pada baris kedua "kembalilah sebelum tersesat" yang diinterpretasikan sebagai instruksi agar jangan terlena terhadap sesuatu yang didapat.

\section{J. Makna Filosofis Metafora dalam Puisi-puisi Mardi Luhung. \\ Makna filosofis ini merupakan} makna berkaitan dengan nilai-nilai filosofis yang terkandung dalam metafora yang pada dasarnya berupa pesan-pesan kehidupan. Untuk mendapatkan makna filosofis pada metafor, diperlukan suatu analisis terhadap keseluruhan makna. Pada rumusan masalah yang pertama sudah dikemukakan mengenai bentuk-bentuk metafor yang dimaknai secara hermeneutik yang dikembangkan melalui beragam simbol-simbol yang terdapat didalam puisi. Interpretasi secara hermeneutik ini merupakan interpretasi yang membuka jalan pikiran peneliti untuk mengaitkan makna kutipan puisi dengan konsep nilai-nilai filosofis metafor yaitu : Nilai Etos, Nilai Logos, dan Nilai Patos. 
Dalam pengaplikasiannya, peneliti mengkategorikan nilai-nilai filosofis yang diambil dari sembilan kategori ruang metafor Michael Halley untuk diambil beberapa puisi yang sebelumnya sudah diklasifikasi oleh peneliti untuk masuk dalam kategori nilai-nilai filosofi makna puisi.

\section{Nilai Etos}

Nilai-nilai Etos adalah nilai yang diperoleh dari sifat/karakter moral. Nilai Etos menempatkan fakta-fakta moral sebagai nilai tertinggi. Fakta-fakta ini berkaitan dengan perilaku moral, sosial dan kultural.

Salah satu nilai Etos dalam puisi Mardi Luhung terdapat pada salah satu petikan dari kategori Human adalah puisi yang berjudul Pulau. Nilai filosofis dalam puisi ini terletak pada simbol mata yang melambangkan sumber dari penghayatan terhadap dunia. Mata digunakan untuk melihat (membidik) wilayah tertentu dari perilaku manusia yang lupa terhadap norma kesopanan. Hal tersebut terdapat pada petikan puisi berikut:

Yang cuma matanya saja menyala. dan dengusnya

pernah mengisi setiap relung-lubang. saat kita

yang telanjang mengingati kelalaian yang sering

merangsek. Sambil membidik bagian tepi pelipis. (Bwn/Pulau/17/Hmn/1)

Pada simbol mata menyala menginterpretasikan nilai-nilai penghayatan manusia terhadap dunia. Setiap jengkal nafas dan hidup dihayati serta perilaku manusia yang terkadang lalai dalam ber etika.

\section{Nilai Logos}

Nilai-nilai logos berkaitan dengan pikiran-pikiran manusia tentang keseimbangan hidup dan kematian. Nilainilai logos memaknai karya sastra sebagai ciptaan yang memiliki nilai-nilai tentang hakekat hidup manusia didunia. Hakekat tersebut bermuara pada diri manusia dalam memandang adanya konsep-konsep hidup yang bermetafor dengan kehidupan seharihari.

Salah satu kategori yang berkaitan dengan nilai-nilai Logos dalam puisi Mardi Luhung adalah kategori Animate yang terdapat pada puisi yang berjudul Durung.

"apa kau kelak akan merindukan aku? "begitu bisik si jagal pada sapi yang akan dijagalnya. Bisik sendirian. Bisik yang ditangkap oleh tampar, lampu dan keliningan yang mengkilat. Keliningan yang tergeletak dengan bau liur sapi yang sengak dan menusuk. Keliningan dengan ukiran rumit (Bwn/durung/33/Anm/1)

Pada petikan puisi tersebut, sapi sebagai tenor dikonsepkan dengan kata jagal yang secara literal bermakna penyembelih hewan. Ada pola pencitraan lain yang memunculkan interpretasi yang berkaitan dengan kurban. Seperti tampar yang biasa digunakan untuk mengikat hewan kurban. Makna filosofis yang muncul adalah pengorbanan manusia untuk mensejahterakan manusia tidak lepas dari peran sapi yang rela mengorbankan tubuhnya demi kebutuhan hidup manusia. Hewan pun (dalam puisi ini) memiliki sikap yang di sandingkan dengan sifat-sifat manusia. Sifat yang berkaitan dengan keseimbangan hidup manusia. Keseimbangan yang dibangun atas dasar pengorbanan nyawa.

\section{Nilai Patos}

Nilai patos memusatkan perhatiannya pada nilai-nilai emosional manusia yang berkaitan dengan simpati maupun empati, perasaan positif dan negatif. nilai-nilai tersebut mewakili ekspresi, reaksi berupa frasa, kata maupun kalimat metafor. Hal tersebut membawa ranah emosi pembaca merasa bahwa pengarang benar dan memikat, seperti rasa 
yakin, percaya, rasa cinta, kasih sayang dan rasa bahagia.

Pada puisi, nilai-nilai patos bertujuan untuk mengetahui perilaku tokoh yang terdapat dalam puisi. Perilaku tersebut berupa simbol-simbol metaforis. Selanjutnya, nilai-nilai patos juga untuk mengetahui proses kreatif pengarang. Dalam hal ini, penelusuran proses kreatif dilihat dari segi penggunaan diksi dan penalaran kata, frasa maupun kalimat yang digunakan oleh penyair.

Salah satu kategori yang berkaitan dengan nilai Patos adalah kategori Living yang terdapat pada puisi yang berjudul Bulu Roma. Pada puisi Bulu roma, nilainilai emotif dalam puisi ini adalah semangat untuk mencari rejeki dari bekerja. Semangat ini merupakan bentuk keyakinan terhadap diri agar tercipta dorongan emosional untuk melakukan tindakan yang sesuai dengan tujuan. Hal tersebut tercermin dari petikan puisi berikut:

... "kami tak mengintip kalian. Kami cuma merasa ada jalan lain mencapai sana. Seperti tangga yang terus terulur. Yang bahannya dari apa yang tak mempan kami beli. Dan bermekaran di bulu roma!'”(BB/Bulu roma/35/Lvg/2)

Pada petikan puisi tersebut ada simbol tangga mengarah pada makna rejeki yang terus terulur. Dalam konteks ini, rejeki merupakan hasil dari buah kerja keras manusia. Nilai patos yang terdapat dalam puisi ini adalah rejeki seseorang ditentukan oleh bagaimana ia mampu bekerja keras, berani dan tanpa putus asa. Hal tersebut ditunjukkan pada kata bermekaran yang dikonsepkan dengan bulu roma yang dapat diinterpretasikan sebagai kerja keras yang berujung pada hasil yang dicapai.

\section{DIKUSI HASIL PENELITIAN}

\section{a) Diskusi Teori}

Penelitian ini secara umum bertujuan untuk menemukan ekspresi metafor dalam puisi-puisi Mardiluhung dari kacamata ruang persepsi metafora Michael Halley yang terdiri dari sembilan ruang persepsi, yakni being, cosmos, energy, substance, terrestrial, object, living, animate, dan human. Menurut Halley (Wahab, 2008:71) ruang persepsi ini sudah berurutan sesuai dengan pemetaan lambang dan karakter yang memiliki hubungan sistematis dalam penggunaan metafora dan makna yang dimaksudkan. kategori yang paling dasar adalah kategori human. Kategori ini merupakan bagian dari kategori selanjutnya yang sudah diatur secara berurutan yaitu animate. Menurut Halley, hierarki persepsi manusia dimulai dari manusia itu sendiri, karena manusia dengan segala macam tingkah lakunya merupakan lingkungan manusia yang terdekat. Jenjang ruang persepsi di atas human adalah animate (makhluk bernyawa) sebab manusia hanyalah satu bagian saja dari makhluk bernyawa. Sebaliknya, tidak semua makhluk bernyawa dapat dimasukkan ke dalam kategori human.

Selanjutnya kategori di atasnya ialah living. Termasuk di sini alam tetumbuhan. Begitu hierarki tersebut seterusnya berjenjang ke atasnya, sampai pada segala sesuatu yang ada dijagad ini, termasuk konsep yang bersifat abstrak yang tidak dapat dihayati oleh indera, walaupun tidak dapat disangkal keberadaannya. Karena itu, kategori ruang persepsi yang paling atas adalah being untuk mewakili semua konsep abstrak yang tidak dapat dihayati dengan indera manusia.

\section{b) Diskusi Temuan}

Analisis ruang persepsi metafora Halley pada Puisi-puisi Mardi Luhung ditujukan pada kata, frasa maupun kalimat yang diidentifikasi sebagai metafora. Pengidentifikasian ini dilakukan dengan pembacaan secara berturut-turut dan 
menandai temuan tersebut kemudia diklasifikasi berdasarkan kategorikategori yang sudah terumuskan. Dalam penerapannya terhadap puisi, metafora Halley tampak hanya sebatas menemukan bentuk dari metafor puisi Mardi Luhung. Dalam arti bukan metafor puisi secara keseluruhan, tetapi hanya pada "tempelan" bait maupun baris yang terdapat dalam puisi. Metafora Halley meyakini bahwa petikan berupa kata, frasa maupun kalimat sudah dapat mewakili karakteristik ungkapan penciptaan puisi melalui metafor. Namun, sepanjang peneliti mengamati dan mempelajari teori-teori metafora Halley dari beragam literatur asing maupun dari media internet, peneliti menemukan bahwa metafora Halley secara teknis hanya mengaplikasikan temuantemuan metafor dalam ranah bentuk. Bukan keutuhan makna. Hal ini dikarenakan metafora Halley tidak mempertimbangkan aspek situasi teks yang lain dalam memaknai sebuah metafora, tetapi mempertimbangkan kedekatannya pada makna literal secara implisit. Misalnya kata kumbang yang mengerubungi bunga dimaknai metafora Halley sebagai lelaki yang memburu perempuan cantik. Konteks ini ada benarnya jika ditarik dari segi konvensi budaya secara umum. Tetapi setiap daerah tentu memiliki interpretasi yang berbedabeda dalam memaknai teks tersebut. Kumbang bisa berarti penjahat jika kita mengacu pada budaya timur Tengah. Bunga bisa bermakna kematian jika mengacu pada budaya Mesir Kuno. Makna tersebut sangat relatif, bergantung dari persepsi dan pengalaman pembaca.

Temuan menarik yang terdapat dalam analisis puisi Mardi Luhung adalah temuan makna yang variatif dari satu judul puisi. Hal tersebut tidak lepas dari peran karakter puisi Mardi Luhung yang bertipikal personifikatif. Benda-benda mati seperti gelas, guci, botol, manik-manik digunakan sebagai konsep dari perilaku manusia. Tidak heran jika prosentase terbanyak dari ruang persepsi metafor berada pada kategori human.

Sumbangsih teori Halley cukup bermanfaat dalam hal merangkum karakter dan pola estetika Mardi Luhung yang bersifat naratif simbolik. Namun, teori metafor Halley pun tidak luput dari kekurangan, yaitu tidak mengaitkannya metafora dengan relevansi simbol. Metafora terletak di akar semiotik, baik ditinjau dari sisi historis maupun analitis. Dari sisi historis, ada tradisi lama tori-teori metafora yang kembali ke Aristoteles (284321 SM). Dari segi analitis, metafora berkaitan dengan kajian tentang tandatanda figuratif dan juga melahirkan pertanyaan yang lebih mendasar apakah makna "harfiah" yang mungkin terjadi. Hal-hal seperti kearbitreran, konvensionalitas, motivasi, dan ikonisitas telah mendominasi pembahasan semiotik tentang metafora.

Menganalisis puisi tanpa didukung oleh persepsi secara simbolik tampak sulit untuk menemukan makna dalam puisi. Metafor Halley tampak sekali merangkum simbol sebagai bagian dari metafor tanpa merinci ciri-ciri simbol yang digunakan oleh ruang persepsi metafor temuannya. Maka dari itu, peneliti mencoba untuk memperluas kajian metafor Halley dengan menanamkan makna filosofis dalam metafor Halley agar tercipta interpretasi yang tidak kaku dan lebih variatif dan dianalisis dengan pendekatan hermeneutik.

\section{SIMPULAN DAN IMPLIKASI}

Metafora tidak dapat dilepaskan dalam penciptaan puisi oleh penyair yang teramati pada larik-larik yang menjadi bagian dari puisi. Metafora tersebut dapat ditemukan dalam bentuk simbol-simbol yang mengandung makna metaforis yang dapat mewakili ruang persepsi manusia.

Berdasarkan hasil penelitian dapat dikemukakan bahwa dalam puisi-puisi 
Mardi Luhung terdapat simbol-simbol metaforis yang mewakili ruang persepsi manusia. Ditemukan 71 simbol yang mengandung ungkapan metaforis yang tersebar pada sembilan jenis ruang persepsi manusia. Jenis simbol tersebut lebih didominasi oleh kategori Human dalam kumpulan puisi $C B y K$ yang ditemukan sebanyak sembilan dari 30 temuan yang diperoleh atau sekitar 30\%. Hal tersebut disebabkan oleh dominasi kata benda baik berupa alam maupun benda sehari-hari yang dikonsepkan dengan perilaku manusia seperti menggunting, memasak, menanam, dan seterusnya.

Ada alasan tertentu Mardi Luhung menggunakan perbandingan makhluk hidup dan benda sehari-hari dengan sifatsifat manusia karena ungkapan metaforis tersebut dimaksudkan untuk memperoleh bentuk-bentuk dan makna simbol sekaligus nilai/makna filosofis dalam puisi-puisi Mardi Luhung. Bentuk, makna simbol dan nilai/makna filosofis disampaikan penyair dengan menggunakan ungkapan-ungkapan metaforis yang melambangkan sesuatu yang konkrit untuk tujuan yang abstrak atau sebaliknya untuk tujuan yang abstrak dengan menggunakan lambang-lambang yang konkrit. Agar lambang-lambang tersebut tidak kering makna, maka peneliti menambahkan makna filosofis yang bertujuan untuk memperluas interpretasi metafora Halley.

Makna filosofis yang memiliki nilai prosentase yang tinggi terdapat pada kumpulan puisi $C B y K$. Nilai etos memiliki prosentase tertinggi dibandingkan dengan logos dan patos. Hal tersebut dikarenakan kumpulan puisi $C B y K$ banyak membandingkan simbol-simbol kemanusiaan yang dikonotasikan dengan karakter moral. Karakter tersebut terbentuk secara metafora konseptual. Metafora konseptual menekankan aspek linguistik puisi yang mengaitkan dengan atribusi subjek dengan source domain (ranah sasaran).

\section{Implikasi Teoritis}

Pada penelitian ini, menghasikan konsep metafor yang berupa paparan diksi, frasa maupun kalimat yang dihasilkan dari ruang ekspresi metafor Halley dengan pendekatan Hermeneutik dan semiotik. Dalam penerapannya, metafora Halley tidak menggunakan pendekatan apapun dalam mengapresiasi metafor. metafor Halley terasa cukup pada ruang ekspresi yang menurut Halley berkaitan dengan pola pikir manusia yang dimulai dari yang konkret hingga ke abstrak. Hal tersebut merupakan rumusan Halley memandang kreativitas manusia dalam menciptakan sebuah ungkapan yang dituangkan dalam teks-teks yang mengandung metafors.

Sementara pada penelitian ini, peneliti mencoba untuk melengkapi metafora Halley melalui pendekatan Hermeneutik dan Semiotik. Kedua pendekatan tersebut saling mendukung perihal pemaknaan metafor yang bersifat simbolik, misalnya ungkapan kumbang mencium bunga, dalam metafora Halley, bisa diindikasikan dua kategori sekaligus, bisa masuk pada kategori human dan animate. Karena kalimat tersebut memiliki unsur yang berkaitan dengan sifat manusia yang ditunjukkan pada mencium, sedangkan kumbang berkaitan dengan animate. Hal tersebut tampak hanya memaparkan metafor sebagai simbol belaka tanpa mempertimbangkan situasi teks yang lain.

Pada ranah Hermeneutik, peneliti melihat situasi bahasa yang dikemukakan oleh penyair melalui diksi yang sering digunakan sebagai citraan metaforis, misalnya kumbang mencium bunga. Kalimat tersebut bisa dilihat pada situasi teks yang lain dengan melihat asosiasi kalimat yang dimaknai secara literal. Sedangkan pada ranah semiotik, peneliti mengklasifikasi simbol yang menentukan tema dari puisi tersebut. Klasifikasi tersebut dilakukan dengan membaca secara 
berulang-ulang serta menggarisbawahi temuan tersebut kemudian dikomparasikan struktur teks, hal tersebut bertujuan untuk menemukan makna dari puisi.

\section{Implikasi Praktis}

Penelitian ini mengimplikasikan teori metafora Halley sekaligus menambah pola pengapresiasian metafora halley dengan mengaitkan situasi teks dalam pemaknaannya. Penelitian ini diharapkan dapat menambah wawasan keilmuan baru dalam menerapkan analisis puisi yang selama ini hanya terbatas pada pemaparan bentuk tanpa menilai makna tersebut pada ranah yang lebih luas dan spekulatif.

\section{DAFTAR PUSTAKA}

Aminuddin. 1997. Stilistika : Pengantar Memahami Bahasa Dalam Karya Sastra. Semarang : CV IKIP Semarang Press

Atmazaki. 1990. Ilmu Sastra : Teori dan Terapan. Padang : Angkasa Raya.

Black, Max, 1962.Models and Metaphors, Ithaca, New York: Cornell University Press.

Bertens, K. 2011. Etika. Jakarta: Gramedia

Casey, E.S. 1976. Imagining: A. Phenomenological Study, Bloomington: Indiana University Press

Cirlot, J.E. 1962. A Dictionary of Symbols. New York: Philosophical Library Inc.

Davidson, Donald, Inquiries into Truth and Interpretation, Oxford: Clarendon Press, 1984.
Edi Subroto. 1996. Semantik Leksikal. Surakarta: Universitas Sebelas Maret Press.

Levin, Samuel R. 1977. The Semantics of Metaphor. Baltimore: The John Hopkins University

Mardiluhung. 2007. Ciuman Bibirku yang Kelabu. Yogyakarta: Akar Indonesia

Mardiluhung. 2011. Buwun. Gresik: Buku Bianglala

Mardiluhung. 2011. Belajar Bersepeda. Gresik: Amper Media.

Mooij, J.J.A 1975. Tenor, Vehicle, and Reference, New York: Columbia University Press

Noth, Winfried. 2006. Semiotik. Terjemahan Prof.Dr. Abd. Syukur Ibrahim. Surabaya: Airlangga University Press.

Ratna, Nyoman Kutha. 2007. Teori, Metode, Dan Teknik Penelitian Sastra. Yogyakarta : Pustaka Pelajar.

Ratna, Nyoman Kutha. 2009. Stilistika. Kajian Puitika Bahasa, Sastra dan Budaya. Yogyakarta: Pustaka Pelajar.

Pradopo, Rachmat Djoko. 1993. Pengkajian Puisi. Yogyakarta : Gadjah Mada University Press

Pilliang, Amir Yasraf. 2003. Hipersemiotika. Yogyakarta : Jalasutra.

Ricoeur, Paul. 2004. Rule of Metaphor. New York: Taylor \& Francis Library. 
Rune, Dagobert D. 1942. Imagination, dalam Dictionary of Philosophy, New York: Philosophical Library

Shapiro, Michael. 2000. The Sense of Grammar. Bloomington: Indiana University Press.

Shihab, Quraish. 2013. Kaidah Tafsir. Tangerang: Lentera Hati.

Siswantoro, 2011. Metode Penelitian Sastra, Analisis Struktur Puisi. Yogyakarta : Pustaka Pelajar.

Sugiharto, Bambang. 2012. Postmodernisme, tantangan bagi filsafat. Yogyakarta: Kanisius.

Sumaryono, E. 1999. Hermeneutik. Yogyakarta: Kanisius.

Teeuw, A. 1983. Tergantung pada Kata. Bandung: Pustaka Jaya.

Zoest, Art van. 1993: Semiotika. Jakarta: Gramedia

Ullman, Stephen. 2008. Semantics. Oxford: Blackwell.

Wahab, Abdul. 2008. Isu Linguistik Pengajaran Bahasa dan Sastra. Surabaya: Universitas Airlangga.

Wellek Rene dan Austin Warren. 2014. Teori Kesusastraan. Terjemahan Melani Budianta. Jakarta: Gramedia Pustaka. 